\title{
Suggestions to Overcome the Problems in Availing the Benefits under National Horticulture Mission
}

\author{
Seema Yadav ${ }^{*}$, K. C. Sharma ${ }^{2}$ and Krishna Yadav ${ }^{3}$ \\ Department of Extension Education, Sri Karan Narendra Agriculture University, Jobner \\ (Jaipur) and ${ }^{2}$ Dean, College of Agriculture Navgaon (Alwar), India \\ *Corresponding author
}

\begin{tabular}{|c|c|}
\hline & A B S T R A C T \\
\hline & \multirow{7}{*}{$\begin{array}{l}\text { India is mainly an agriculture based country where majority of the people are engaged in } \\
\text { agriculture. Diversified and boosted growth in agriculture is dependent upon the } \\
\text { development of horticulture sector. Recognizing the importance of horticulture in } \\
\text { stimulating the growth of Indian agriculture, government of India had launched National } \\
\text { Horticulture Mission for the holistic development in the year of } 2005-06 \text {. The present } \\
\text { study was undertaken to measure the suggestions to overcome the problems in availing the } \\
\text { benefits under National Horticulture Mission in Jaipur and Tonk districts of Rajasthan. A } \\
\text { total of } 240 \text { beneficiary farmers were included in the sample of study. Study shows that } \\
\text { 'Subsidies should be increased for more areas and beneficiaries' was most important } \\
\text { suggestion given by majority of the beneficiary farmers with overall MPS } 87.08 \text { and was } \\
\text { ranked first. The second most important suggestion given by the beneficiary farmers was } \\
\text { 'Provide adequate information about various schemes included in the programme at right } \\
\text { time with } 85.69 \text { MPS. The least important suggestion was 'Supply of modern hi-tech farm } \\
\text { implements under NHM to beneficiaries at subsidized rates' with MPS } 61.58 \text {. }\end{array}$} \\
\hline & \\
\hline Horticulture & \\
\hline $\begin{array}{l}\text { Mission, } \\
\text { Beneficiary }\end{array}$ & \\
\hline $\begin{array}{l}\text { farmers, Training, } \\
\text { Subsidy }\end{array}$ & \\
\hline Article Info & \\
\hline $\begin{array}{l}\text { Accepted: } \\
10 \text { July } 2020 \\
\text { Available Online: } \\
10 \text { August } 2020\end{array}$ & \\
\hline
\end{tabular}

\section{Introduction}

India is mainly an agriculture based country where majority of the people are engaged in agriculture. Indian agriculture is an important factor for sustainable development and poverty alleviation. Even today agriculture sector is the main source of livelihood and food security for major population in India. Horticulture has emerged as an important sector of diversification agriculture and emerged as a growth engine of agriculture. Diversified and boosted growth in agricultural is dependent upon the development of horticulture sector. It plays a pivotal role in improving the productivity of land, generating employment, enhancing exports and improving the socio-economic status of the farmers.

Recognizing the importance of horticulture in stimulating the growth of Indian agriculture, Government of India had launched a scheme of National Horticulture Mission for the holistic development of this sector. It is a centrally sponsored scheme, launched by the 
Department of Agriculture \& Cooperation, Ministry of Agriculture, Government of India during 2005-06. NHM plays a crucial role in promoting growth in horticulture and helps in augmenting growth in Indian agriculture. NHM playing a important role in increase in area as well as productivity of horticultural crops through motivation of farmers, providing subsidy, guidance and other facilities. It also plays an important role in improving the living standard of the farmers. NHM scheme includes production and productivity improvement of horticulture crops by supplying quality planting material, nurseries, rejuvenation of senile orchards, protected cultivation, cold storage facilities, integrated nutrient management, integrated pest management, production of organic farming and deploying honeybees for enhancing productivity through cross pollination. It is always important to find out the suggestion for improvement in the implementation of NHM to make the future programme more effective.

\section{Materials and Methods}

Among different Agro Climatic Zones of Rajasthan, Semi-arid Eastern Plain (IIIA) Agro Climatic Zone was selected for the study purpose. This Agro Climatic Zone comprises of four districts namely;- Jaipur, Ajmer, Tonk and Dausa. Out of these Jaipur and Tonk districts were selected for the research study on the basis of maximum number of beneficiary farmers under selected activities of NHM. From Jaipur district 6 tehsils were selected namely;- Amber, Chomu, Shahpura, Jhotwara, Sambhar and bassi. From Tonk district also 6 tehsils were selected namely;- Newai, Malpura, Tonk, Uniara, Todaraisingh and Deoli, those having maximum number of beneficiaries under selected activities of NHM. A list of beneficiary farmers under selected activities of NHM (farmers benefited from the year
2014 to 2016) from selected districts were prepared. From that list 30 per cent of beneficiary farmers were selected by using simple random sampling in proportionate from each tehsil and selected activities under NHM. These activities were selected on the basis of highest number of farmers taking benefits under NHM. Thus, a total of 240 beneficiary farmers were included in the sample of study. The investigator collected data by using personal interview method. The collected data were analyzed. For knowing the suggestions of respondents mean percent score for each statement was calculated and ranked accordingly.

\section{Mean Percent Score (MPS)}

Mean Percent Scores were obtained by multiplying total obtained score of the respondents by hundred and divided by the maximum obtainable score under each practice. Formula is given as under:

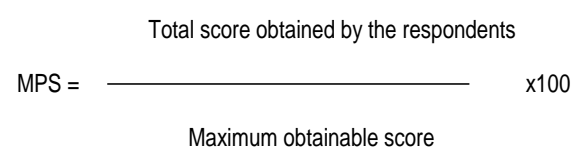

\section{Rank}

Ranks were accorded in the descending order according to the mean per cent score obtained. This was used to prioritize different items of the awareness, utilization, training needs and constraints to show their order of priority.

\section{Results and Discussion}

Suggestions to overcome the problems in availing the benefits under NHM

An attempt was also made to ascertain suggestions from beneficiary farmers to overcome various problems faced by them in availing the benefits under NHM. The 
beneficiary farmers were requested to offer their valuable suggestions against difficulties faced by them in availing the benefits under NHM. The suggestions given by the beneficiary farmers were collected and the MPS was calculated for each statement and ranks were assigned accordingly. The results have been presented in Table 1 .

It is evident from the data presented in Table 1 that 'Subsidies should be increased for more areas and beneficiaries" was most important suggestion given by majority of the respondents with overall MPS 87.08 and was ranked first. The second most important suggestion was 'Provide adequate information about various schemes included in the programme at right time' with 85.69 MPS. The next most important suggestion was 'Quantity of inputs should be increased" with 79.17 MPS and was ranked third, followed by 'The rates of subsidy need to be increased considering the prices of inputs and wages' with 78.47 MPS and was ranked fourth and 'Total subsidy amount should be given in one time' with 75.55 MPS and was ranked fifth.

It is clear from data presented in Table 1 that 'Training must be given to beneficiaries regarding scientific post harvest management practices' and 'Arrangement for transport facilities at fair prices should be made for farmers to sell their farm produce' were the least important suggestions given by majority of the respondents with MPS 66.39 for both and was ranked twelfth.

The fourteenth least important suggestion given by the respondents was 'Subsidy should be given as soon as the work is completed' with 64.58 MPS. The next least important suggestion was 'Training about processing and marketing facilities should be given for the sale of products' with 61.94 MPS and was ranked fifteenth, followed by 'Supply of modern hi tech farm implements under NHM to beneficiaries at subsidized rates' with overall 61.58 MPS and was ranked sixteenth.

The other suggestions reported by the beneficiary farmers were 'Make easy and speedy procedure for getting benefits under NHM' (MPS 75.42), 'Input material given should be of good quality' (MPS 74.58), 'Crop insurance system may be initiated for horticultural crops under NHM' (MPS 72.78), 'Government should fix the prices of fruits and vegetables every year' (MPS 70.83) and 'Marketing infrastructure in terms of market hub and terminal markets be maintained to have forward and backward linkages' (MPS 67.78) and 'Initiation of processing activities and value addition of horticulture crops' (MPS 67.08).

In case of district wise in Jaipur district, it is evident from the data presented in Table 1 that 'Subsidies should be increased for more areas and beneficiaries' was most important suggestion given by majority of the respondents with MPS 86.90 and was ranked first. The second most important suggestion was 'Provide adequate information about various schemes included in the programme at right time' with 83.81 MPS. The next most important suggestion was 'The rates of subsidy need to be increased considering the prices of inputs and wages' with 80.95 MPS and was ranked third, followed by 'Make easy and speedy procedure for getting benefits under NHM' with 79.52 MPS and was ranked fourth and 'Quantity of inputs should be increased' with 79.04 MPS and was ranked fifth.

It is evident from the data presented in Table 1 that 'Marketing infrastructure in terms of market hub and terminal markets be maintained to have forward and backward linkages' was least important suggestion given by majority of the respondents with MPS 64.52 and was ranked twelfth. 
Table.1 Distribution of beneficiary farmers according to their suggestions

\begin{tabular}{|c|c|c|c|c|c|c|c|}
\hline \multirow[t]{2}{*}{$\begin{array}{l}\text { S. } \\
\text { No. }\end{array}$} & \multirow[t]{2}{*}{ Suggestions } & \multicolumn{2}{|c|}{$\begin{array}{c}\text { Jaipur district } \\
\mathrm{n}_{1}=\mathbf{1 4 0}\end{array}$} & \multicolumn{2}{|c|}{$\begin{array}{l}\text { Tonk district } \\
\mathbf{n}_{2}=100\end{array}$} & \multicolumn{2}{|c|}{$\begin{array}{c}\text { Overall } \\
\mathbf{n}=\mathbf{2 4 0}\end{array}$} \\
\hline & & MPS & Rank & MPS & Rank & MPS & Rank \\
\hline 1. & $\begin{array}{l}\text { Subsidies should be increased for more areas } \\
\text { and beneficiaries }\end{array}$ & 86.90 & I & 87.33 & II & 87.08 & I \\
\hline 2. & $\begin{array}{l}\text { Provide adequate information about various } \\
\text { schemes included in the programme at right } \\
\text { time }\end{array}$ & 83.81 & II & 88.33 & I & 85.69 & II \\
\hline 3. & $\begin{array}{l}\text { Subsidy should be given as soon as the work } \\
\text { is completed }\end{array}$ & 64.28 & XIII & 65.00 & XVI & 64.58 & XIV \\
\hline 4. & $\begin{array}{l}\text { The rates of subsidy need to be increased } \\
\text { considering the prices of inputs and wages }\end{array}$ & 80.95 & III & 75.00 & V & 78.47 & IV \\
\hline 5. & $\begin{array}{l}\text { Government should fix the prices of fruits } \\
\text { and vegetables every year }\end{array}$ & 66.90 & IX & 76.33 & IV & 70.83 & IX \\
\hline 6. & $\begin{array}{l}\text { Training about processing and marketing } \\
\text { facilities should be given for the sale of } \\
\text { products }\end{array}$ & 53.81 & XVI & 73.33 & VI & 61.94 & $\mathrm{XV}$ \\
\hline 7. & $\begin{array}{l}\text { Make easy and speedy procedure for getting } \\
\text { benefits under NHM }\end{array}$ & 79.52 & IV & 69.67 & XII & 75.42 & VI \\
\hline 8. & Quantity of inputs should be increased & 79.04 & V & 79.33 & III & 79.17 & III \\
\hline 9. & $\begin{array}{l}\text { Input material given should be of good } \\
\text { quality }\end{array}$ & 77.86 & VII & 70.00 & XI & 74.58 & VII \\
\hline 10. & $\begin{array}{l}\text { Total subsidy amount should be given in one } \\
\text { time }\end{array}$ & 78.09 & VI & 72.00 & VIII & 75.55 & V \\
\hline 11. & $\begin{array}{l}\text { Arrangement for transport facilities at fair } \\
\text { prices should be made for farmers to sell } \\
\text { their farm produce }\end{array}$ & 64.05 & XIV & 69.67 & XII & 66.39 & XII \\
\hline 12. & $\begin{array}{l}\text { Crop insurance system may be initiated for } \\
\text { horticultural crops under NHM }\end{array}$ & 74.52 & VIII & 70.33 & $X$ & 72.78 & VIII \\
\hline 13. & $\begin{array}{l}\text { Supply of modern hi-tech farm implements } \\
\text { under NHM to beneficiaries at subsidized } \\
\text { rates }\end{array}$ & 55.00 & $\mathrm{XV}$ & 70.67 & IX & 61.58 & XVI \\
\hline 14. & $\begin{array}{l}\text { Marketing infrastructure in terms of market } \\
\text { hub and terminal markets be maintained to } \\
\text { have forward and backward linkages }\end{array}$ & 64.52 & XII & 72.33 & VII & 67.78 & $X$ \\
\hline 15. & $\begin{array}{l}\text { Initiation of processing activities and value } \\
\text { addition of horticulture crops }\end{array}$ & 65.46 & $\mathrm{X}$ & 69.33 & XIV & 67.08 & XI \\
\hline 16. & $\begin{array}{l}\text { Training must be given to beneficiaries } \\
\text { regarding scientific post harvest } \\
\text { management practices }\end{array}$ & 64.76 & XI & 68.67 & $X V$ & 66.39 & XII \\
\hline & Total & 71.22 & & 73.58 & & 72.20 & \\
\hline
\end{tabular}


The thirteenth least important suggestion was 'Subsidy should be given as soon as the work is completed' with 64.58 MPS. The next least important suggestion was 'Arrangement for transport facilities at fair prices should be made for farmers to sell their farm produce' with 64.05 MPS and was ranked fourteenth, followed by 'Supply of modern hi-tech farm implements under NHM to beneficiaries at subsidized costs' with 55.00 MPS and was ranked fifteenth and 'Training about processing and marketing facilities should be given for the sale of products' with 53.81 MPS and was ranked sixteenth.

In Tonk district, it is evident from the data presented in Table 1 that 'Provide adequate information about various schemes included in the programme at right time' was most important suggestion given by majority of the respondents with MPS 88.33 and was ranked first. The second most important suggestion was 'Subsidies should be increased for more areas and beneficiaries' with 87.33 MPS. The next most important suggestion was 'Quantity of inputs should be increased' with 79.33 MPS and was ranked third, followed by 'Government should fix the prices of fruits and vegetables every year' with 76.33 MPS and was ranked fourth and 'The rates of subsidy need to be increased considering the prices of inputs and wages' with 75.00 MPS and was ranked fifth.

It is evident from the data presented in Table 1 that 'Arrangement for transport facilities at fair prices should be made for farmers to sell their farm produce' and 'Make easy and speedy procedure for getting benefits under NHM' were least important suggestions given by majority of the respondents with MPS 69.67 and was ranked twelfth. The next least important suggestion given by respondents was 'Initiation of processing activities and value addition of horticulture crops' with 69.33 MPS for both and was ranked fourteenth, followed by 'Training must be given to beneficiaries regarding scientific post harvest management practices' with 68.67 MPS and was ranked fifteenth and 'Subsidy should be given as soon as the work is completed' with 65.00 MPS and was ranked sixteenth. These findings are supported by Shanti (2010), Dipika et al., (2014), Uma (2014), Sandeep et al., (2014), Singh et al., (2015), Khandave and Suryawanshi (2015) and Balkrishna (2016).

In conclusion the study shows that 'Subsidies should be increased for more areas and beneficiaries' was most important suggestion given by majority of the beneficiary farmers with overall MPS 87.08 and was ranked first. The second most important suggestion was 'Provide adequate information about various schemes included in the programme at right time' with 85.69 MPS. The least important suggestion was 'Supply of modern hi-tech farm implements under NHM to beneficiaries at subsidized rates' with MPS 61.58.

\section{References}

Balkrishna, A.G. (2016). Socio-economic impact of National Horticulture Mission on its beneficiaries in Marathwada region. Ph.D. Thesis, Department of Extension Education, Vasantrao Naik Marathwada Krishi Vidyapeeth, Parbhani (Maharashtra).

Dipika, D.A.; Lairenlakpam, M. and Kokate, D.S. (2014). Constraints faced by the farmers in adoption of turmeric production technology. Gujarat Journal of Extension Education. 25(2) pp: 215217.

Khandave, S.R. and Suryawanshi, P.S. (2015). Impact of National Horticulture Mission on beneficiaries. Journal of Agriculture Research Technology. 40(2), pp: 348-350.

Sandeep,Y.; Prajapati, R.R and Prajapati, 
M.R. (2014). Knowledge and adoption of tomato growers about improved tomato production technology. Gujarat Journal of Extension Education. 25(2) pp: 172-174.

Shanti Nirmala (2010). A Study on Rythu Chaitanya Yatra a farmer empowerment programme in Mehboobnagar district of Andhra Pradesh. M.Sc. (Agri.) Thesis. Acharya N.G Ranga Agricultural University, Hyderabad.

Singh, K.; Shekhawat, S.S. and Ghintala, A.
(2015). Problem faced by the beneficiaries in availing the benefits under National Horticulture Mission. Indian Journal of Extension Education and Rural Development. 23, pp: 87-89.

Uma, Prasher (2014). Mahatma Gandhi National Employment Guarantee Act and its impact on the beneficiaries. Asian Journal of Research in Social Sciences and Humanities. 4(4), pp: 5060 .

\section{How to cite this article:}

Seema Yadav, K. C. Sharma and Krishna Yadav. 2020. Suggestions to Overcome the Problems in Availing the Benefits under National Horticulture Mission. Int.J.Curr.Microbiol.App.Sci. 9(08): 162-167. doi: https://doi.org/10.20546/ijcmas.2020.908.017 